\title{
GREAT BLUE HERON COLONIES IN SASKATCHEWAN IN 1970
}

by Kees Vermeer, Canadian Wildlife Service, Edmonton, Alberta, and Gary G. Anweiler, Melville, Saskatchewan

A survey of nesting colonies of Great Blue Herons was made in Saskatchewan in the summer of 1970 to obtain information on distribution, size, and habitat of heronries. Heronries were located by asking naturalists and wardens if they knew of colonies in their areas and by searching appar ently suitable habitat along rivers and around lakes. As the survey was no exhaustive, colonies may have beer missed, and further information or heronries unknown to the writers wil therefore be much appreciated.

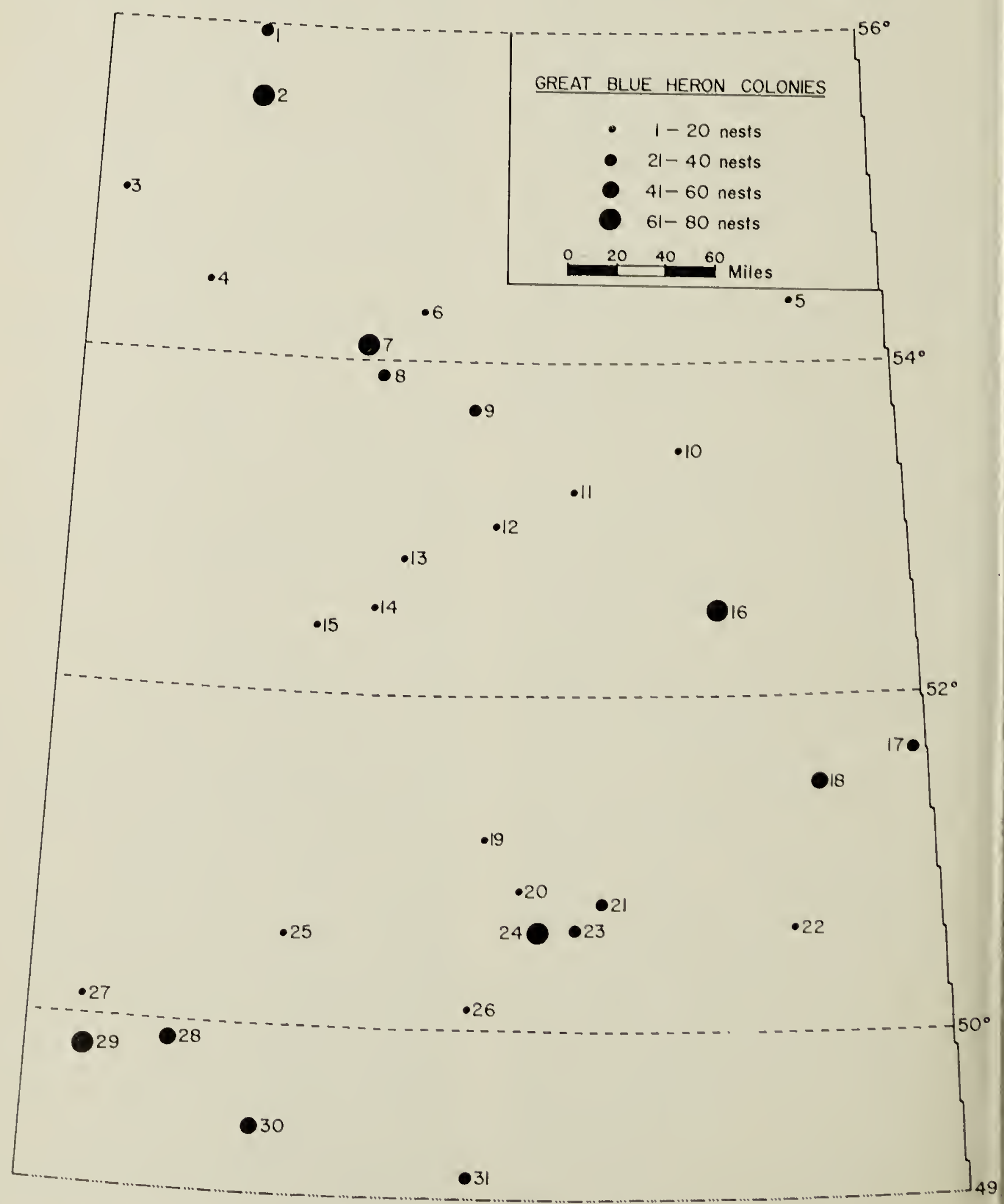

Fig. 1. Great Blue Heron colonies in Saskatchewan, 1970. 
Thirty-one active heronries were located in Saskatchewan in 1970 as shown in Figure 1. Numbers in that figure correspond to colonies shown in Table 1. The number of nests ranged from 1 to 75 , and the mean colony size was 26.8 . This is not significantly different $(\mathrm{P}>0.05)$ from the mean colony size of 21.3 nests of 27 colonies ranging from 1 to 55 observed in Alberta in 1967 (K. Vermeer, 1969, Great Blue Heron colonies in Alberta. Can. FieldNat., 83:237-242). Of the 31 active colonies 17 were located near rivers and creeks, 12 on lake islands and two near lake shores.

Sixty per cent of 15 colonies north of Saskatoon, $50^{\circ} 07^{\prime} \mathrm{N}$, were on lake islands as compared to only 19 per cent of 16 colonies south of that city. For the same latitude in Alberta it was 81 and 19 per cent respectively. The large percentage of colonies found on lake islands north of the above latitude may be related to the greater availability of lake islands there than in the southern parts of Alberta and Saskatchewan.

As in Alberta (Vermeer, 1969), Great Blue Herons in Saskatchewan chiefly nested in poplar trees over 20 feet in height (Table 2). Mixed colonies of Black-crowned Night and Great Blue Herons were found in chokecherry bushes at Old Wives Lake and in low buffalo berry bushes along the

Table 1. Location and size of Saskatchewan Great Blue Heron colonies in 1970.

\begin{tabular}{l|r|r|r|r}
\hline \multicolumn{1}{|c|}{ Water body } & No.nests & Section & Township & Range \\
\hline 1. Churchill Lake & 21 & - & 80 & $16 \mathrm{~W} 3$ \\
2. Kazan Lake & 75 & 13 & 76 & $16 \mathrm{~W} 3$ \\
3. Primrose Lake* & 20 & 11 & 69 & $25 \mathrm{~W} 3$ \\
4. First Mustus Lake & 14 & 4 & 63 & $19 \mathrm{~W} 3$ \\
5. Suggi Lake & 1 & 15 & 62 & $6 \mathrm{~W} 2$ \\
6. Lavallée Lake & 15 & - & 61 & $4 \mathrm{~W} 3$ \\
7. Delaronde Lake & 64 & 5 & 60 & $8 \mathrm{~W} 3$ \\
8. Delaronde Lake & 40 & 2 & 57 & $7 \mathrm{~W} 3$ \\
9. Anglin Lake & 40 & 10 & 55 & $27 \mathrm{~W} 2$ \\
10. Saskatchewan River & 8 & 1 & 52 & $14 \mathrm{~W} 2$ \\
11. Saskatchewan River & 16 & 20 & 49 & $21 \mathrm{~W} 2$ \\
12. South Saskatchewan River & 6 & - & 46 & $26 \mathrm{~W} 2$ \\
13. North Saskatchewan River & 2 & 16 & 44 & $5 \mathrm{~W} 3$ \\
14. North Saskatchewan River & 5 & 34 & 40 & $7 \mathrm{~W} 3$ \\
15. North Saskatchewan River & 15 & 26 & 39 & $11 \mathrm{~W} 3$ \\
16. Marean Lake & 70 & 6 & 41 & $11 \mathrm{~W} 2$ \\
17. Madge Lake & 30 & - & 31 & $30 \mathrm{~W} 1$ \\
18. Horseshoe Lake & 50 & 2 & 29 & $5 \mathrm{~W} 2$ \\
19. Arm River & 2 & 14 & 25 & $28 \mathrm{~W} 2$ \\
20. Arm River & 4 & 2 & 22 & $26 \mathrm{~W} 2$ \\
21. Qu'Appelle River & 25 & 28 & 20 & $20 \mathrm{~W} 2$ \\
22. Qu'Appelle River & 7 & 12 & 19 & $7 \mathrm{~W} 2$ \\
23. Qu'Appelle River & 24 & 26 & 19 & $22 \mathrm{~W} 2$ \\
24. Buffalo Pound Lake & 65 & 31 & 18 & $24 \mathrm{~W} 2$ \\
25. Swift Current Creek & 13 & 34 & 18 & $13 \mathrm{~W} 3$ \\
26. Old Wives Lake* & 5 & 29 & 13 & $29 \mathrm{~W} 2$ \\
27. Tenaille Lake & 5 & 28 & 13 & $26 \mathrm{~W} 3$ \\
28. Bone Creek & 43 & 8 & 11 & $20 \mathrm{~W} 3$ \\
29. Harris Reservoir & 26 & 27 & 2 & $30 \mathrm{~W} 2$ \\
30. Frenchman River & & 10 & $26 \mathrm{~W} 3$ \\
31. Southwest of Fife Lake & 50 & 5 & $15 \mathrm{~W} 3$ \\
\hline
\end{tabular}

*Not visited in 1970. Counts at Primrose and Old Wives Lakes made in 1968 and 1969 respectively. 
Table 2. Tree habitat of active Great Blue Heron Colonies.

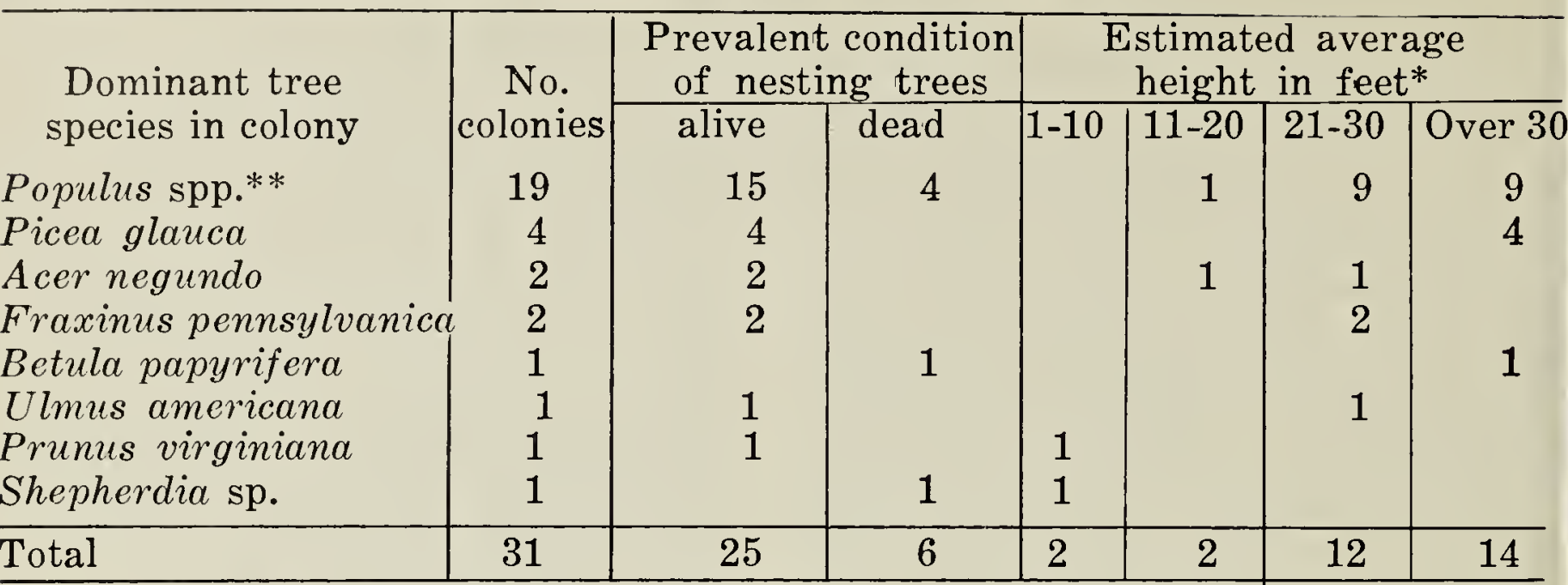

* Height in one colony unknown

**Mostly Populus balsamifera and P. tremuloides

Frenchman River. In the latter colony were also four nests of Canada Geese. Great Blue Herons nested together with Double-crested Cormorants in birches and aspen poplars at Kazan Lake. The cormorants occupied the lower branches. Five heronries were observed to contain one Great Horned Owl nest each and one pair of Ospreys bred in a heronry along the Saskatchewan River near Nipawin.

At least 20 heronries are known to have disappeared in Saskatchewan over the years (Table 3 ). Nine of those ceased to exist in the 1960's. Five colonies appear to have disappeared because of disturbance by shooting (Crane Lake-Skull Creek), hail (Fairwell Creek), flood (Middagh Lake), tree cutting (Whitewood Lake) and nest robbing (Qu'Appelle River, No. 13). Causes of decline in the other 15 colonies are unknown. Active colonies have also been disturbed by the above causes. A rancher dwelling near the active heronry at Swift Current Creek reported that many young herons were killed during a hailstorm

Table 3. Great Blue Heron colonies no longer active in Saskatchewan.

\begin{tabular}{|c|c|c|c|c|}
\hline Water body & Section & \begin{tabular}{|l|} 
Location \\
Township
\end{tabular} & Range & $\begin{array}{c}\text { Last year } \\
\text { known to breed }\end{array}$ \\
\hline 1. Ministikwan Lake & 17 & 58 & $25 \mathrm{~W} 3$ & $1968 \pm 1$ \\
\hline 2. Delaronde Lake & 27 & 57 & $7 \mathrm{~W} 3$ & $1965 \pm 2$ \\
\hline 3. Paddling Lake & 10 & 46 & $7 \mathrm{~W} 3$ & $1930-1940$ \\
\hline 4. Acton Lake & 30 & 45 & $13 \mathrm{~W} 3$ & 1932 \\
\hline 5. Basin Lake & 27 & 42 & $23 \mathrm{~W} 2$ & $1920 ?$ \\
\hline 6. North Saskatchewan River & & 41 & $15 \mathrm{~W} 3$ & $1938 \pm 2$ \\
\hline Lizard Lake & 36 & 38 & $14 \mathrm{~W} 3$ & 1958 \\
\hline 8. Whitewood Lake & 27 & 29 & $17 \mathrm{~W} 2$ & $1943 \pm 2$ \\
\hline 9. Last Mountain Lake & & 28 & $24 \mathrm{~W} 2$ & 1932 \\
\hline 10. Middagh Lake & 9 & 24 & $4 \mathrm{~W} 3$ & 1950 's \\
\hline 11. Pearl Creek & 28 & 19 & $7 \mathrm{~W} 2$ & Late 1960 's \\
\hline 12. Qu'Appelle River & 23 & 19 & $12 \mathrm{~W} 2$ & Late 1950 's \\
\hline 13. Qu'Appelle River & 4 & 19 & $11 \mathrm{~W} 2$ & Late 1950's \\
\hline 14. Qu'Appelle River & 1 & 18 & $33 \mathrm{~W} 1$ & 1969 \\
\hline 15. Pipestone Creek & & 15 & $4-5 \mathrm{~W} 2$ & $1968-1969$ \\
\hline 16. Pipestone Creek & 19 & 12 & $31 \mathrm{~W} 1$ & $1967 \pm 1$ \\
\hline 17. Crane Lake - Skull Creek & & $12-13$ & $22-23 \mathrm{~W} 3$ & 1906 \\
\hline 18. Scott-Ray Lake & 21 & 10 & $3 \mathrm{~W} 2$ & Early 1960's \\
\hline 19. Sandy Lake & 16 & 10 & $4 \mathrm{~W} 2$ & 1965 \\
\hline 20. Fairwell Creek & 31 & 6 & $24 \mathrm{~W} 3$ & $1963 \pm 1$ \\
\hline
\end{tabular}


in 1966 and that the colony has been subsequently reduced in size. He also reported that one person took a few dozen eggs from that colony in 1969. Yost (pers. comm.), dwelling in the vicinity of the active heronry southwest of Fife Lake, reported that the herons probably moved from west of Rock Glen to their present site because of human disturbance. The birds still are shot at occasionally but Mr. Yost does what he can to prevent this. We hope that readers will watch vigilantly for any form of human disturbance to heronries in their locality.

\section{Acknowledgments}

Many naturalists and wardens provided information or gave assistance in locating heronries. Special thanks go to Dr. C. S. Houston, Saskatoon, who provided a detailed list of heronries, D. W. A. Whitfield, Saskatoon, who located several new heronries along rivers by plane, R. Isbister, Edmonton, who surveyed the heronries at Churchill, Kazan and Lavallée Lakes and J. E. Polson and T. Donald, who conducted a brief and preliminary survey in 1969.

\section{A THIRD RED-BELLIED WOODPECKER RECORD FOR SASKATCHEWAN}

\section{by Frank H. Brazier, 2657 Cameron Street, Regina}

Reclining at ease in the shade of several tupelos, popularly known as "black gums", I often watched the comings and goings of a family of Red-bellied Woodpeckers at a feeder in a Louisiana garden. I also saw this attractive and distinctive bird often during a recent visit to Florida.

Because I am familiar with the Redbellied Woodpecker (Centurus carolinus) through my travels in the southeastern United States, I was sure when I wandered into Manley Callin's front yard at Fort San, Saskatchewan, on July 19, 1970, that a woodpecker which landed on a power-line pole about 100 yards away belonged to this species. A Yellow-shafted Flicker was nearby on the pole, so I could see that the newcomer was smaller, about Hairy-sized. The size of the bird and the absence of the typical Hairy Woodpecker pattern when viewed sideways at that range sent me racing for my binoculars which I had left in my car. A few seconds later my $10 \times 50$ 's brought it well into viewing range. It had obligingly shifted a quarter-turn to the left around the pole, giving me a fieldguide view of the back; the red over part of the nape, the gray crown and the fine-barred back left no doubt that I was seeing a Red-bellied Woodpecker. The size of the nape patch indicated a female.
This was the third Red-bellied Woodpecker I had seen in Saskatchewan, and I was sure that it would be a first record for Fort Qu'Appelle and the vicinity, and a "lifer" for Manley Callin. Unfortunately, however, Manley failed to hear my call and I had to run in to get him. Returning, we scoured the neighbourhood fruitlessly for some time. Then, when poking through the bush bordering a meadow (those who were at the first annual June field meeting of the Saskatchewan Natural History Society and saw the breeding Yellow-breasted Chat would know the spot), a bird flashed by and perched briefly on a dead tree limb before vanishing into the foliage, long enough for me to get a few seconds' view through the glasses. It was enough to convince me, though I had only a low-angle look, that it was the same bird.

Saskatchewan's first Red-bellied Woodpecker, a female, was seen in the Legislative Grounds in Regina on May 23-26, 1959 (Blue Jay, 17:95). I had seen that bird and, at practically the same spot, on October 12, 1961, a male of this species flew to a tree within a few feet of me. Lucy Eley later mentioned that she had seen a Red-bellied Woodpecker in that vicinity on about that date. 